\title{
LE CODE DE LA NATIONALITE BELGE: A CITIZENSHIP LAW IN THE MAKING
}

Adina Madularea

University of Ottawa

\begin{abstract}
In April 2010, the most recent process was initiated regarding the revision of law on the acquisition of Belgian nationality. A strong debate on the subject had been going on during 2010-2011. This research paper focuses on the positions held by different political parties and representatives with regard to the main issues included in numerous amendments brought to the existing Belgian Nationality Code. Looking at the way in which different aspects have been formulated and debated will provide insights about the stakes of different political actors involved and the process of political negotiation on a very sensitive territory, namely that of citizenship granting in a country with a federal government and a significant cleavage between its main ethnic groups.
\end{abstract}




\section{Introduction}

In April 2010, shortly before its fall, the Belgian government Leterme II had reached an agreement on the revision of law on the acquisition of Belgian nationality. The Code of Belgian Nationality was last reformed in 2000. In its current form, it contains the most flexible conditions for acquiring citizenship among the countries of the European Union (EU). The Code therefore, seems to contradict current European trends in citizenship law, which often promote a "thickening" of citizenship law through the introduction of language and integration requirements. For this reason, a new reform of the Belgian citizenship was expected, not only in order to follow the European trends, but also because internally, critics have pointed out that easy access to citizenship brings along the risk of eroding the value of Belgian citizenship. I will therefore argue that the change of citizenship law, and consequently the debate around it, is driven by three key influences: the European context, Belgium nationalism, and political parties' ideologies. I will focus on the latter two factors, using the general change in the orientation of citizenship laws in Europe as a backdrop against which the Belgian case will be analyzed.

The debate on citizenship law in Belgium has particular features given the country's unique situation characterized by structural pluralism, which was granted to historically recognized linguistic and regional groups (the Walloons and the Flemish) (Winter 2011). Within this context, the ample discussion regarding the Nationality Code is demonstrated in numerous amendments (comprised in no less than 18 documents registered at the Chamber of Representatives). These amendments reveal the complex negotiations between the most powerful ethnic groups. One should also not forget that all the official documents bear the mark of their ideological era. In this situation, it is the ideology of their promoters (different political parties and coalitions), as well as that of the present time that are expected to guide the understanding of this official exchange of opinions.

The present paper focuses on the positions held by different political parties and representatives with regard to the main issues included in the numerous amendments brought to the current Belgian Nationality Code, the stakes of different political actors involved, and the process of political negotiation on a very sensitive territory - namely that of granting citizenship in a country with a federal government and a significant cleavage between its main ethnic groups. In the following sections, I present the context of this research, namely the political and administrative particularities of Belgium. I will then present a brief overview of the two theoretical perspectives that help frame the debate on nationality law in Belgium before discussing the methodological approach. Finally, this paper will highlight the results of this empirical analysis and what these results mean for Belgium's nationality law on the one hand, and European trends in citizenship laws on the other.

\section{Background}

A few contextual details are necessary with regard to the particular situation of Belgium as a federal state, as well as to the current law on citizenship and main features of immigration in Belgium. Belgium has a "highly decentralized federal system" (Seidle 2008, 6) defined by:

- three regions (the Flemish region, the Walloon region, and the Brussels-Capital region);

- and three language communities (Dutch language within the Flemish community, French language within Wallonia-Brussels federation, and German language within the German speaking community) 
The federal government holds the decision making on the legislation of nationality, while the reception and integration of immigrants is a regional and communal matter. Belgium's complex organization also implies a complicated political scene where unilingual political parties compete against each other at the provincial level within the same linguistic group (except the officially bilingual Brussels) while sharing power at the federal level. ${ }^{1}$

The actual nationality law in Belgium relies on the use of the jus soli (territoriality) principle alongside the jus sanguinis (parentage/family links) principle. As opposed to the majority of EU countries, and as a consequence of the 2000 reform, Belgium has a less restrictive naturalization policy - a foreign citizen can acquire Belgian nationality after just three years of legal residence in the country. Moreover, citizenship can also be acquired by a simple "declaration of citizenship" after seven years of legal stay. Under the current citizenship law, there are no official language requirements and no official tests to assess the knowledge of participants with regard to local values, culture, or history.

In terms of linguistic and civic integration, the main difference is between the Flemish community and the Walloon community, which also represent the main poles of dynamics in the political arena. As Jacobs and Rea $(2006,11)$ point out, the issue of integration has been considered by the Flemish authorities within "a cultural vision of the nation" (ethnos) while the Walloons "tend to privilege the demos (a political vision of the nation)." As a consequence, the policy of "inburgering" (the process of becoming a citizen) has been promoted within Flanders territory with the purpose of facilitating immigrants' insertion into the Flemish society. According to the official "inburgering" website, immigrants residing on the Flemish territory are provided with an individual "civic integration trajectory" consisting in a social orientation course, Dutch language course, and support to find a job in the labour market. The Walloon government has adopted no particular measures towards the linguistic integration of adult immigrants. Although there are French language and literacy courses offered, as well as social, cultural, and civic information, Wallonia "takes a more liberal approach, with the immigrant being responsible for his/her own integration" (Seidle and Fourot 2008, 3). Therefore, no official enforcement with regard to integration has been put in place in Wallonia as opposed to Flanders where this policy is very well articulated and includes administrative fines for not complying with the civic integration requirements. ${ }^{2}$

All things considered, while the Flemish community is generally characterized by an ethnocultural orientation, the French-speaking community "is conceived more in politico-civic terms" (Foblets and Yanasmayan 2010, 280). The approach to integration in the Brussels-Capital region

1. Traditional parties (Catholic and Liberal), as well as more recent ones (Socialist and Green) operate on each side of the linguistic border. More precisely, the Christian Democrats are represented in Flanders by Christian Democrat and Flemish Party (Christen-Democratisch en Vlaams, CD\&V) which is also the country's largest party and by the Democratic and Humanist Center (Centre démocratehumaniste, $\mathrm{cdH}$ ) in Wallonia. Open Flemish Liberals and Democrats (Open VlaamseLiberalen en Democraten, Open VLD) is the Liberal party in Flanders while MouvementRéformateur (MR) is its equivalent in Wallonia. Among newer political parties that play a role on the political scene of Flanders, there should be mentioned the right wing, conservative and nationalist movement New Flemish Alliance (Nieuw-VlaamseAlliantie, N-VA), the green party Groen!, and the far-right, self-proclaimed radical, nationalist, and republican party, Flemish Interest (VlaamsBelang, VB). In Wallonia, there is the Francophone ecologist party (Ecolo) which made a coalition with its Flemish counterpart and the Social Democratic party (PartiSocialiste, PS).

2. As mentioned in the article $25 \S 2$ of the Decree on the Flemish integration policy from 28 February 2003, in cases of failure to comply, immigrants can be fined between 50 and 5000 euros depending on the seriousness of the infringement (European Commission 2003)). 
is rather "hybrid," being influenced by the approaches of the other two regions (Le Texier 2006, 2). Moreover, the political dynamics behind these main regions is much more complex, implying not only the opposition between the parties of one region against those of the other region, but also a significant degree of variation within parties in terms of political fights and diverse views. The present research focuses on the difference between parties' views concerning the different amendments proposed for the citizenship law.

What is more, Belgium is often seen as a country of immigration and has welcomed immigrants for a variety of historical reasons (Loobuyck and Jacobs 2009; Le Texier 2006; Martiniello and Rea 2003). The active process of recruiting foreign workers (for coal mines at first, then for other industrial sectors) was initiated soon after the Second World War through bilateral agreements with Italy, Spain, Greece, Morocco, Turkey, Tunisia, Algeria, and Yugoslavia. In addition, workers from the European Community were allowed free movement to Belgium for extended periods of time and were eventually granted residence permits (Martiniello and Rea, 2003). Immigration has been, moreover, propelled by the numerous family reunification requests, by asylum seekers and refugees, and by the relaxed residence requirements for citizenship resulting in the 2000 reform of the Nationality Code $^{3}$ (Seidle 2008, 2). As a consequence, 9.11 percent (around 971 000) of the Belgian population has foreign nationality out of which more than 354000 live in the Flemish region, 322000 in Wallonia, and the rest (around 295 000) in the Brussel-Capital region (Direction générale Emploi et marché du travail 2009). ${ }^{4}$ It should also be added that the composition of immigrant communities differs significantly between Flanders and Wallonia. In Flanders, most immigrants have Turkish or Moroccan origins, while in Wallonia the majority of immigrants are from southeastern Europe (Foblets and Yanasmayan 2010, 281).

Over time, immigration has been acknowledged to bring significant economic contributions. However, politically speaking, the permanent presence of immigrants has encouraged the debate with regard to citizenship and integration policies. In conclusion, Belgium's complex regional, political, and demographic histories provide an important context for which the bill on Belgian citizenship law was born.

\section{Literature Review}

The debate about the Belgian nationality law can be explained from two different perspectives that are equally important. First, this debate can be situated within a body of literature that examines the changes of citizenship laws and citizenship ideology at the international and European levels. The second perspective concentrates on an in-depth understanding of intergroup relations within Belgium and on Belgian identity and "cultural idioms" with regard to nationality and varying ideologies about immigrant integration. This paper will now briefly outline both perspectives.

First, at the European level, "citizenship has become more communitarian and civic republican in character" as serious criteria of civic orientation and language knowledge have

3. Three years of residence requirement for most immigrants (instead of five) and two years for refugees.

4. In 2007, the Italians (17.39 percent of the total population with foreign origin), French (13.44 percent) and Dutch (12.7 percent) were the most important communities of European origin while Moroccans (8.22 percent) and Turks (4.07 percent) are the main non-EU communities

(http://www.emploi.belgique.be/publicationDefault.aspx?id=28778, accessed December 20, 2012)

5. The term 'cultural idiom' was used by Rogers Brubaker (1992) to define a dominant and historically rooted national style of thought on nationhood and citizenship in a country. 
been introduced among the citizenship granting requirements (Van Oers et al 2010, 320). Within the context of a so-called "crisis of multiculturalism," the reaffirmation of the nation-state's sovereignty through its old institution of citizenship was seriously called into question. As a consequence, states have made "recent efforts to upgrade and re-nationalize citizenship by ceremony, civic integration tests and more exclusive rights" (Joppke 2010a, 9). Zapata-Barrero synthesizes the intensely discussed transformation of citizenship as follows:

While the de-nationalization of citizenship has been the main trend since the early 90s, recently several old European host countries (like Denmark, the Netherlands, Germany, France and the United Kingdom) have put strong emphasis on the need to consolidate the citizenship/nationality link and even re-nationalize citizenship, by making it dependent on restrictive cultural requirements, like language and civic tests, and have introduced symbolic ceremonies. $(2009,7)$

However, in Joppke's vision (2010a, 29), these are rather "desperate efforts" in front of the "inevitable lightening of citizenship" illustrated by the "court-driven empowerment of EU citizenship" which is seen as "a citizenship of our time, entirely free of the baggage of nationhood and nationalism." In other words, the innovative construct of EU citizenship indicates an inevitable dissociation between citizenship and nationhood. But until then, we can still speak about an "assimilative civic integration" which both communitarians and republicans agree upon, although for different reasons: "while the first aims at identification with shared cultural values in society (nationalism), the second aims at participation in the political community and civil society" (Zapata-Barrero, 2009, 12). However, it should also be noted that the changes to the citizenship acquisition process in Belgium and other European countries are primarily aimed at third-country nationals and less at European Union citizens, who do not really need to change citizenship.

Coming back to the second perspective and the literature that is concerned with Belgium's particular situation, a closer look at the history of the two communities is necessary to better understand what animates the positions held in the debate of the bill to amend the citizenship law. The idea of "cultural boundaries" needs to be employed in this analysis as Belgium is often described "as the crossroads of two cultures" (Gysen et al 2009, 101). More exactly, "the country is seen as the symbolic borderline between an Anglo-Saxon differentialistic model of multiculturalism in northern Europe and a Latin universalistic model of integration and the making of a multicultural society in southern Europe" (101). But, in light of changes made in the 2000s to citizenship acquisition procedures in different countries across Europe, the traditional frameworks for analyzing national models need to be rethought of since the "old categories of nationalism" (collectivist-ethnic, collectivist-civic and pluralist-civic models) are now "very blurred" (Wright 2008, 7). This happened precisely because formerly "multicultural" or civic citizenship promoting countries (like Denmark and the Netherlands) have moved towards restricting their boundaries and citizenship laws, while Germany (traditionally an ethnic nation/with "blood-based" citizenship) has eased its citizenship laws.

Jacobs and Rea (2006) provide interesting insights about the particularities of the two poles of the political axis, Flanders and Wallonia. Culture and language seem to be traditionally at the centre of the Flemish community's concerns. For the Flemish "acknowledgement and recognition of ethnic identity is seen to be a legitimate endeavour" as reaction to the francophone cultural domination that lasted over a century — and despite the fact that the Flemish represent the 
majority (14). On the other hand, because of its early industrialization, Walloonia-once the economic bastion of the country (Béland and Lecours 2005, 693) - holds at present "a minority position" in the federal state, is "heavily dependent on Flemish (financial) solidarity," and faces "an assertive Flanders which is pleading for more and more autonomy" and independence (Jacobs and Rea 2006, 14).

Linguistic cleavages between the two communities could also explain the disputes between the two. From one standpoint, the Flemish identity "is still very much defined by the Dutch language" as a consequence of the history and "the continuing linguistic tensions" (Béland and Lecours, 2005, 693). From another standpoint, the Flemish language, although spoken by the majority in Belgium, is "less prestigious and international[ly] useful than French" (Woehrling $2007,17)$. On a final note, consideration should also be given to what Jacobs (2011) calls the "fundamentally contrasting visions" of the political representatives of two Communities regarding cultural diversity and national identity - that is, that "the Flemish stress the importance of linguistic and cultural assimilation, while acknowledging at the same time the importance of ethnic identity, and the Francophones stress identity-blind inclusion in a political demos" (2).

Within the context of these two perspectives, certain questions arise, mainly how do these groups' cultural differences, as well as the global trends in understanding citizenship, influence the debate on the recent changes to the Belgian nationality law, and what influences do the parties' ideologies have in this story?

\section{Methodology}

The methodological approach for this paper relies on a thematic content analysis of the $18 \mathrm{draft}$ law proposals and amendments debated by the Belgian Chamber of Representatives between 2010 and 2011. This method goes beyond the observable, and allows one "to identify implicit as well as explicit themes" comprised in the data (Merton 1975, 336). In thematic analysis, the coding scheme is based on categories designed to capture the dominant themes in a text (LewisBeck et al 2004, 186). Therefore, the purpose is rather exploratory aiming to understand rather than to know the data.

Initially, the list of themes is identified deductively, starting from the most recent provisions of citizenship laws provided by the literature (e.g. naturalization procedure, legal residence, integration courses, language criteria etc.). Next, the distinction between important and peripheral themes is made based on the degree of attention (in terms of number of arguments and implicitly number of pages) given to the particular themes in the proposed amendments.

The analysis will then reveal details about the major categories of changes and their supporters, as well as information about the controversies with each issue. The findings will be explained by placing them within the wider context of the Belgian situation and the current global debate regarding the definition of national citizenship. The approach will provide an interesting perspective on the Belgian political arena, as well as its most active actors and their interests with regard to different aspects of granting citizenship to newcomers.

In the undertaken approach, I first propose an overview of the key issues brought into the national citizenship debate. I will then focus on the most relevant aspects of the debate, namely the most controversial ones, and their significance within the Belgian context. The reader should bear in mind that the documents under investigation are examined from a sociological point of view, i.e. attention is given to the actors and the justification of the suggested amendments; the precise legal formulation of these amendments are beyond the scope of this paper. 


\section{Analysis}

\section{Key Motivations for the New Law}

In identifying and categorizing the major issues tackled by the citizenship law amendments, the starting point is represented by the draft law amending the Belgian Nationality Code (dating from March 1 2000) and presented to the Council of Ministers in April 2010 by Justice Minister Stefaan De Clerck, who also belongs to the Christian Democrat and Flemish Party (CD\&V) and is one of its former leaders. ${ }^{6}$

The key motivation for the proposed changes is to make "the acquisition of Belgian nationality neutral from the immigration's point of view" (De Clerck 2010b, 2). This neutrality is explained further in terms of granting the Belgian nationality only to those persons that are "lawful residents" of Belgium. More concretely, it implies stricter conditions for obtaining Belgian nationality, namely holding a permanent residence card at the moment of request and showing the "willingness to integrate" or "volonté d'integration". The latter aspect is correlated to "the knowledge of one of the national languages" and "the participation in the community life" (De Clerck 2010a, 2). In other words, stronger links to the Belgian territory and culture, as well as the good behaviour of potential citizens are required. Within this context, the word "neutral" may rather be interpreted as an expression of political correctness, as the actual requirements clearly point towards the citizenship applicant's obligations.

The first draft also calls to attention the fact that naturalized citizens can lose their citizenship if "they have been sentenced for a criminal offence showing evident hostility towards Belgian society or used their Belgian nationality to commit criminal offenses." Belgian citizenship may also be taken away from individuals who have acquired it through "marriage of convenience" (De Clerck 2010a, 2).

The same draft defines several key elements that are poorly defined in the current citizenship law and that consequently resulted in "inconsistent and incoherent implementation of Code's provisions" (De Clerck 2010a, 3). First, is the notion of legal residence, which, in the Minister's opinion, needs to be clarified in terms of content for "obvious reasons of good administration and legal security" (3). Legal residence refers to holding 'principal residence' in Belgium and a permanent legal residence at the moment of submitting the application for citizenship. Moreover, the process of acquiring Belgian nationality can no longer be initiated or unfolded from abroad. Therefore, the territorial links to Belgium are primarily enforced. Then, the notion of "real/authentic ties to Belgium," which, although enclosed in the law from June 28 1984, has rather been "left at the discretion of competent authorities" with no clear criteria (De Clerck 2010a, 7-8). It is proposed in this respect an "exhaustive list" on what is meant by real/authentic

6. There should be also noted few contextual details: CD\&V was the largest political formation in the government assembled in 2008. In April 2010, Open-VLD left the government due to some controversial matters left unresolved. The event implied the government dissolution and consequently accentuated the Belgian political crisis characterized by tense communal relations and political instability that eventually lasted until the end of 2011. After the federal elections held on June 2010 and resulting in the New Flemish Alliance (N-VA) winning most votes in the Flemish-speaking area and the Socialist Party (PS) in French-speaking one, Belgium had for 541 days an interim government as no agreement could be reached among the parties on a coalition to form a new government (Rolf Falter, "Breaking up is hard to do," Crisis in Belgium Blog, December 10, 2011, http://crisisinbelgium.blogspot.ca /2011/12/breaking-up-is-hard-to-do.html). 
ties. There are objective criteria showing one's "anchorage" and involvement in the host society:

- Knowledge of one of the official languages

- Duration of stay in Belgium

- Regular contact with Belgian residents

- Attendance at school of one of the national languages

- Holding property in Belgium

- Direct connections with Belgium at the social or professional level

Concrete details about whom the "competent authority" is and in what way these criteria are going to be evaluated seem to be missing. It is, however, mentioned that residence in Belgium is mandatory in this respect and that at least two criteria need to be fulfilled.

The naturalization procedure, although constitutionally considered as a "favour granted by the legislative power to a person judged as "particularly deserving," has in its current form minimal conditions of access ("Currently, the procedure of naturalization is open to foreigners of eighteen years and more, having their principal residence in Belgium for at least three years") (De Clerck 2010a, 8). In this context, and in line with the claimed motivation of this draft of the bill, naturalization is proposed to require five years (instead of three) of permanent residence as a prerequisite and it should also involve the knowledge of one of the official languages, along with the applicant's willingness to participate in the life of the host community (which are not directly and concretely stated in the current citizenship law). This aspect is translated into the candidate's "ability to cope with ordinary events that are part of his/ her daily life" and it should be evaluated in an individual manner to avoid "the exclusion of the categories of "vulnerable' people" (e.g. older or less educated people) (9). To reinforce the applicant's real connection with the Belgian territory, no more citizenship submissions from abroad are accepted.

In conclusion, the first draft amending the Belgian Nationality Code suggests the profile of a person that is well integrated and connected to various parts of the host community's life, yet no concrete criteria of evaluation are stated. In other words, the ideology of the center-right Flemish party (namely the individual's insertion in the community) is integrated as guiding principle in the proposed reform (through its author, former CD\&V leader), but it is not completely depicted in operational terms.

\section{Parties' Positions}

Overall, while examining the 18 amendments proposed subsequent to the first submission of the bill by different members of parliament, it becomes clear that the initiative, and the most active role in debating the bill on citizenship, belongs to the Flemish parties as they submitted approximately two thirds of the amendments.

Regardless of the number of amendments submitted, it is interesting to look at the parties' declared motivations, with regard to changing the nationality law. The Flemish liberal party, Open VLD, translated its liberal, progressive, and social ideology into the bill by emphasizing the importance of a successful integration of immigrants in the community and understanding between different ethnic groups. The integration criteria are seen as essential in this respect as they can also "maximize the likelihood of success of a model of harmonious society" (Belgian H.R. 0476/001 2010,6). Although it does not clearly state what "success" looks like or how it will be measured, Open VLD emphasizes the importance of a clear definition of integration criteria as they seen to be essential for successful integration in the community. As a 
consequence, Open VLD proposes that the integration criteria listed below be considered for all the procedures regarding the acquisition of citizenship:

- Attending an integration course (organized by the Communities)-as a sign of willingness to integrate;

- The knowledge of the official language of the region of main residence - perceived as essential element for integration;

- And a statement agreeing to comply with the democratic rule of law and fundamental rights - as a sign of the good intentions (Belgian H.R. 0476/001 2010, 7)

The criteria added by the liberal Flemish party with regard to immigrants' integration approach suggests a policy of assimilation, mingled with "integration" in which the host society dictates the terms of assimilation that would imply a change in a linear progression from "foreign attributes to host citizen attributes" (Ghaffar-Kucher 2006, 3). Unfortunately, the statements extracted from the empirical material lack concrete details about the actual implementation of these requirements.

The right wing political party New Flemish Alliance, N-VA, aims at bringing more political coherence to the Belgian nationality, which currently has "the most flexible citizenship law in Europe" (Belgian H.R. 0574/001 2010, 3). The guiding principles suggested by them reflect their orientation towards civic nationalism with rational and liberal objectives:

- Neutrality from the immigration point of view which implies a sufficiently long and uninterrupted stay in Belgium as eligibility criteria;

- Objectivity regarding the conditions for obtaining the citizenship;

- Social legitimacy, namely that the citizenship could be obtained only by the persons capable of proving sufficient integration in the society;

- Genuine engagement in the sense that serious offenders are not eligible to obtain citizenship;

- And uniformity of procedures by reducing the number of measures needed to acquire Belgian citizenship (3).

Looking at the N-VA interventions in the debate of the Belgian Code of Nationality, it appears that the above-mentioned claims of neutrality, objectivity, social legitimacy, and genuine engagement do regard exclusively the citizenship applicants and imply the necessity of assisting them to assimilate. In line with their objectives, N-VA proposed the idea of implementing a process of integration ("parcours d'intégration") (Belgian H.R. 0476/003 2010, 13) as defined by the competent authority at the Community level. According to the party, this parcours should be considered as a "serious condition" for the acquisition of nationality, yet no concrete details are offered in terms of who is actually the competent authority, what would comprise such a parcours or how its completion would be evaluated. Nonetheless, the party's pleading for the competence of the Communities in this respect is a reminder of the Flemish policy of inburgering and the party's desire to preserve the status quo, from this point of view, as a guarantee for the possibility to impose the Flemish language in Flanders along with a an immigrant's integration process enforced by the federal law.

The far-right political party, Flemish Interest (Vlaams Belang, VB), translated its ideology in a proposal aimed at bringing stricter conditions "the drastic way," implying the evaluation of the candidate's willingness to integrate through a citizenship exam (Belgian H.R. 0618/ 001 2010). Its representatives also propose to replace the "nationality" ("nationalite") term by "citizenship" ("citoyennete") as the two terms are, in fact, not seen as synonyms within the Belgian context. Therefore, citizenship would be, in their opinion, a more suitable and neutral notion. 
In line with their ideology of rejecting multiculturalism ${ }^{7}$ ), they argue that strong cultural differences contribute to the appearance of cultural enclaves as potential sources of conflict (Belgian H.R. 0618/ 001 2010, 3) ${ }^{8}$. Denouncing the multiculturalism utopia, in which the facility with which Belgium grants citizenship to non-Europeans plays an important role, they conclude that "granting of the citizenship cannot precede the integration, but it should rather be the culmination of successful integration" (Belgian H.R. 0618/001 2010, 4).

Being the most vocal anti-immigration party, VB tries to appeal to voters through its antiimmigration and, in particular, anti-Muslim sentiment. They propose, therefore, to "re-establish the right of blood" (jus sanguinis) and, besides that, make the naturalization procedure the only method of acquiring citizenship. The latter one should include more and tougher conditions in order to avoid the perception of nationality as "a means to obtain rights" (Belgian H.R. 0618/ $0012010,4)$. In this respect, a citizenship test should evaluate the level of integration of the candidate, and their knowledge of the official language of their region of residence, as the primary indication of integration. Tests in the United States and Canada are given as examples, although they are easier than the citizenship tests implemented in different European countries. However, clear details are offered by VB on the contents of their proposed citizenship test: a written and oral citizenship test organized by each Community (and held in one of the official language of the Community) should evaluate the knowledge of fundamental rules of the society as well as the history and culture of the community the candidate is a part of (Belgian H.R. 0618/ $0012010,6)$.

The VB also propose to limit or even eliminate the plurality of citizenship by asking the candidates to give up their previous citizenship as multiple citizenships encourage "looking for the deals" and claiming the citizenship that offers the most benefits under the particular circumstances. Moreover, they sustain that naturalization should be the means "par excellence" to obtain Belgian citizenship motivating that if the citizenship is too easily acquired there is no motivation for integration (Belgian H.R. 0618/ 001 2010, 6). Therefore, in their view, there should not be an option to acquire citizenship by declaration or based on jus soli, as well as no citizenship for the third generation (grandchildren of Belgium citizens who do not live in Belgium and who claim Belgian citizenship based on the blood ties they have with the country through their grandparents). Vlaams Belang's advocacy for strict limits on immigration is obvious in this pleading, as well as the high standards imposed on the candidate: he/she should be able to pass a complicated citizenship exam, have no juridical condemnations, and have the proof of financial means and no fiscal debts.

On the Walloon side, the French-speaking liberal party, Mouvement Réformateur (MR), motivate their proposal for a more neutral citizenship law by emphasizing the necessity to reinforce the conditions of obtaining citizenship as well as imposing objective conditions with regard to the naturalization process (Belgian H.R. 0601/ 001 2010). The key point of their approach is the necessity to better "control" the immigration phenomenon in which the

7. They mainly criticize multiculturalism for the threat posed by the so-called "ghettoization"

8. "We find in our towns numerous examples of "little Morocco" or "little Turkey". The security offered by this ghetto, where the ethnic solidarity prevails and where the Islam sets point of reference in a "hostile" world, makes unnecessary any contact with the 'Belgians'." ["On trouve, dans nos villes, de nombreux exemples de "petit Maroc" ou de "petite Turquie". La sécurité qu'offre ce ghetto, où prime la solidarité ethnique et où l'islam sert de point de repère dans un monde "hostile", rend superflu tout contact avec les "Belges"] (Belgian H.R. 0618/ 001 2010, 3). 
citizenship law plays an important role. More exactly, according to this party, Belgian nationality should not be chosen "to reinforce an illegal or precarious administrative status," but rather as a personal choice shown through the candidate's "willingness to integrate" in the country of residence (Belgian H.R. 0601/ 001 2010, 4).

For the MR's representatives, "the acquisition of nationality must keep a solemn character" in the sense that it should not be just an administrative process that allows a foreigner to stay in a given area. On the contrary, it must start from the strong will of a person to join a country, to enjoy the rights it provides and also be subject to the obligations imposed upon nationals (4).

Their civic orientation is also brought into the discourse by emphasizing the necessity of "a deep societal reflection" on "what does Belgium mean today?" (Belgian H.R. 0601/ 001 2010, 7). In ideological terms, MR seems to be on the same page with the Flemish parties in terms of citizenship granting as result of the integration's success. They plead, however, for a unitary vision in terms of integration, instead of the currently fragmented field determined by the fact that integration is the Community's responsibility and the two Communities have different approaches in this respect.

Specific elements of Francophone elites' discourse focused on socio-economic indicators with regard to immigrants' integration, which could be noticed in the emphasis placed on "the need to give a true meaning to the process of requesting the Belgian citizenship" by ensuring "decent life conditions" and asking for the "respect of the universal values of the country" (Belgian H.R. 0601/ 001 2010, 15). In line with the constitutional description of the citizenship as a "favour and not a right," MR representatives consider that citizenship should be seen as a symbol of gratitude offered by the nation to deserving foreigners. Therefore, the naturalization process should be accompanied by a "real demonstration of willingness to integrate" (Belgian H.R. 0601/ 0012010,7$)$. In this respect, the following criteria are proposed:

- Seven years of residence;

- Knowledge of one of the official languages;

- A sufficient knowledge of the universal values, institutions and history of Belgium proved by any legal means;

- No condemnations for criminal acts.

Mouvement Réformateur agrees with Flemish parties, in that a demonstration of a certain "attachment" to Belgium, including the knowledge of one or more national languages, is required. However, they suggest considering Belgium as a whole and not as distinct communities as the latter view would imply a form of "sub-nationalities against the Constitution" (DOC 0476/ $0032010,6)$.

The allied interventions of the Green parties from both regions, Groen! in Flanders and Ecolo in Wallonia, in the 2010-2011 debate on the Belgian Code of Nationality were rather limited and concerned the addition of certain nuances to requirements regarding the permanent residence in Belgium, citizenship granting to children with a Belgian parent, and the limited role of the state's official in citizenship granting (Belgian H.R. 0476/ 007 2011; Belgian H.R. 0476/ 008 2011).

Initially, the Socialist Party (Parti Socialiste, PS) did not have a distinct stance in the debate on the citizenship law. Its representatives' contributions were more concerned with clarifying certain terms or administrative situations including the notions of "main residence," "legal stay," or the naturalization procedure (Belgian H.R. 0742/ 001 2010; Belgian H.R. 0476/ 002 2010). However, in a third intervention signed by no less than eight PS members, new perspectives were introduced with respect to the procedures of obtaining Belgian citizenship including 
language knowledge, proved integration in the community, and exceptional merits for Belgium (Belgian H.R. 0476/ 009 2011). Therefore, the Socialist Party proposes

- A short procedure of obtaining citizenship through declaration after five years of legal stay and with the condition of knowledge of one of the official languages, in order for the candidate to prove that he/ she can cope with ordinary events from their daily life (Belgian H.R. 0476/ 009 2011, 13);

- A long procedure after ten years of legal stay that implies the knowledge of one of the national languages correlated to applicant's proved integration in the community of residence, and that is evaluated in terms of involvement in the life of his/her neighbourhood, having children in school, belonging to a cultural or sports association, positive feedback on behalf of the acquaintances from the neighbourhood etc. (13);

- A naturalization procedure for persons older than 18 years of age, whose main residence is in Belgium and who received the title of honoris causa (merits that add prestige to Belgium at scientific, sport, cultural, or social level) or doloris causa (pain caused by catastrophes in Belgium or persecution in the country of origin.), elements for the first time introduced in the debate. The request should be accompanied by a motivation letter sent to the Chamber of Representatives, the superior forum for naturalization procedure (Belgian H.R. 0476/ 009 2011, 6).

The main ideas introduced by the PS ("rationalized procedures of citizenship acquisition" and "exceptional merits") along with the other intensely debated issues (language knowledge, main residence, and legal stay) are considered in a final and concerted intervention of the main Flemish parties, except VB (Open-VLD, N-VA, CD\&V, sp.a) ${ }^{9}$ aimed at bringing an integrative perspective on citizenship acquisition. They tried to harmonize different points of view expressed in previous amendments and "simplified" the modalities of acquiring Belgian citizenship into five "clear and unambiguous" procedures (Belgian H.R. 0476/ 010 2011, 19).

- In case of citizenship acquisition by declaration, besides the requirement of legal stay in Belgium (five years for the short procedure and ten years for the long one), the emphasis is on "proof of knowledge of one of the official languages," "social integration" (translated into educational programs in Belgium, namely minimum secondary studies or 400 hours of professional training or completion of a course of integration), and "economic participation" (at least two years of full employment) (Belgian H.R. 0476/ 010 2011, 5-8).

- Citizenship through naturalization is granted in "exceptional cases" and the PS representatives' idea of "exceptional merits" (honoris causa) that could bring a contribution to the international reputation of Belgium is key in this respect (Belgian H.R. 0476/ 010 2011, 11).

- A fee of 150 euros (idea initially proposed by MR) for the procedure of nationality acquisition is also introduced. This fee is thought to be high enough to have a deterrent effect on persons making records without any real chance of success (Belgian H.R. 0476/ $0102011,30)$.

On 19 July 2012, a version of amendments for the Belgian Citizenship Law close to the latest intervention passed with a large majority the Justice Committee of the Belgian Parliament and (Wautelet, 2012) and on 25 October, it was sent to the Senate for further approval (Belgian H.R. 0476/ 021 2012).

9. Socialistische Partij Anders (Different Socialist Party) (sp.a) is the Flemish counterpart of the Parti Socialiste. 


\section{Discussion: Convergent and Divergent Dimensions of the new Citizenship Law}

Overall, there are several aspects that, in general, the Belgian parties agree with; I call these the uncontroversial issues. They are in line with what most parties seem to agree with in the campaign of the 2007 federal elections, namely that more "dignity" should be given to the Belgian nationality with regard to the following aspects (Loobuyck and Jacobs 2009). First of all, the nationality "should not be just a right of residence," referring to the fact that Belgian citizenship should be made more valuable and, for that reason, more difficult to acquire. Then, it is claimed the necessity of uninterrupted and permanent legal residence in Belgium as a prerequisite for any kind of application for citizenship. In the words of Open VLD representatives, Belgium should represent "the center of the candidate's socio-economic interests" for a number of years prior to applying for citizenship. Moreover, for the Flemish Liberal Party, Open VLD, legal residence "de durée indeterminée" (for an undetermined length) is an expression of applicant's "rootedness" in the territory of the host country (Belgian H.R. 0476/ 001 2010, 6). An exhaustive list describing "real/authentic ties to Belgium"-accepted by many representatives from both linguistic groups in its initial form-will be considered a good change in comparison to the actual ambiguousness of the term.

The objective criteria of acquiring citizenship translated in the proposal's main provisions are:

- Five years of legal stay (instead of three) along with the applicant demonstrating the ability to speak one of the national languages (seen as a proof of their willingness to integrate into the host society) and evidence of economical integration (by two years of employment);

- Ten years of legal stay (instead of seven) accompanied by the evidence of applicant's participation in the life of its host community as the preconditions for the so called "declaration of citizenship."

- Immediate withdrawal of citizenship in the case of a naturalized citizen's condemnation for serious crimes against Belgium or making illegal use of the Belgian nationality. Marriages of convenience are penalized in the same manner and stricter rules have been suggested for acquiring the citizenship on the basis of marriage (a longer period of common life and even proofs on the acquisition of real/authentic ties with Belgium).

The most controversial issue refers to the language requirements and it is mainly a consequence of divergent visions on citizenship between Flemish and Walloons parties. In the debate on the linguistic requirements in relation to citizenship and integration, several aspects stand out from different amendments made by different political representatives to the draft proposal of the new Belgian nationality law.

On the one side, Flemish parties sustain the importance of language assimilation, namely requiring that applicants for nationality demonstrate knowledge of "the national language of their place of residence" (Belgian H.R. 0476/ 001 2010, 14). The arguments brought in this respect regard the fact that knowledge of the language is "a determinant element for integration" and that "a successful integration is of paramount importance for the harmonious coexistence of people with different backgrounds" (Belgian H.R. 0476/ 005 2010, 3). Furthermore, speaking and understanding the language of the community is crucial in this respect. The Flemish parties insist 
on transferring this responsibility to the regional level. Language courses, education diplomas, and citizenship tests have also been mentioned with respect to the tightening of the reform of nationality law

On the other side, there are Francophone parties who agree with the Flemish ones regarding the knowledge of the language; yet, they believe the length of residence in Belgium is also relevant. A critique against Flemish parties' proposals is that tying language knowledge to the place of residence will result in the organization of "sub-nationalities" (Belgian H.R. 0476/ 003 $2010,2)$. Instead, "the whole Belgian territory should be considered as society of reference" for granting the Belgian nationality (Belgian H.R. 0476/ 003 2010, 3). Therefore, the representatives of Francophone parties consider that the language criteria should be regarded in a more flexible manner - "the requirement of language knowledge shouldn't be a barrier to acquisition of nationality, but rather a means to facilitate integration" (3). In other words, language is an integration vector. They are also arguing for reciprocity regarding the path of integration which equals the fact that any of the three national languages of Belgium should be equally accepted ("independent of the applicant's place of residence" (3).

\section{Conclusions}

In this contribution, I have tried to explain the debate of the bill regarding the Belgian nationality law from the perspective of the undoubted influence of the European trends on citizenship law, as well as internal cultural differences, along with main political actors and their stakes. From the former point of view, it is clear that the reform of Belgian nationality law follows the path of "renationalizing citizenship" through the particular attention given to civic integration. In this respect, integration courses and integration conditions for the naturalization procedure, as well as language requirements have been proposed, thus shifting the focus towards more subjective elements that regard one's integration into the society. The new proposal follows the model of other European countries that have raised the bar for citizenship applicants. This influence could be explained from the perspective of a certain convergence in migration and integration policies observed among the European countries in the sense that "governments seem to have retracted from extreme positions on the continua (determined by the traditional and distinctive forms of nationalism--collectivist-ethnic, collectivist-civic, and pluralist-civic) to inhabit a middle ground" (Wright 2008, 5). One of the causes of this apparent convergence could be the sharing of "best practices" in the area of migration, and coordinating cooperation as "political networks become more transnational" (7). The idea of bringing the Belgian citizenship law "in line" with the "new European legislations" is also sustained by the Christian Brotcorne, the author of the report done on behalf of the Justice Committee when the proposed new Belgian Nationality law passed in the Belgian Parliament's Justice Committee with a large majority (DH 2012) ${ }^{10}$.

On the other hand, Belgium's unique federation of three regions and three official languages, linguistic cleavages and divergent views on immigrants' integration between main ethnic groups favours long debates, especially when an issue with such complex implications is at stake. The official positions held by different parties from the far-right VB to moderate Flemish parties and the Francophone liberal party reflect the ideologies they promote as well as the interests of the present. They agree on the necessity of adding value to the Belgian citizenship by paying attention to the candidate's willingness to integrate. However, some controversies are not yet

10. "Par cette nouvelle loi, la Belgique s'inscrit ainsi dans la ligne des nouvelles législations européennes en la matière" (DH 2012). 
resolved and they refer to integration and language criteria and the extent to which they should be tied to the Community. Within this context, a significant role is played by the Flemish elite's interest to promote the Dutch language and the Francophone elite's interest to "let the candidate choose," which go hand in hand with their views on an immigrants' integration (assimilation with recognizing ethnic minorities integrated in inburgering policy in Flanders vs. neutral forms of individual social insertion in Wallonia). Both parties have big stakes, especially in the debate between "the language of the place of residence" and "one of the three official languages."

Although Flanders forms the majority and is more powerful from the economical point of view than Wallonia, its language is more vulnerable than French (as many immigrants might consider the French language more useful or they may have already learned it in their native countries and consequently might prefer it for their integration in Belgium). Moreover, each of the regions has reason to use immigration as an issue that will enhance its position. And, according to Jacobs $(2011,3)$, the big battle is in Brussels Capital Region where there are more than 1.1 million inhabitants (representing approximately ten per cent of the population) that produces 20 percent of the Belgian Gross National Product (with a significant number of Francophone people who live in the Flemish periphery of Brussels and a significant number of Flemish people who commute to Brussels on a daily basis). Therefore, "for cultural, socioeconomic, political, symbolic, and historical reasons, Brussels is of high importance for all regions of Belgium, and none of the linguistic communities can afford to give up the federal capital" (3). For the Flemish representatives the fear is that, in the absence of pressure to learn Flemish, more and more immigrants in Flanders will choose the French language and consequently affect the unity of the Community. On the other hand, Wallonia is interested in increasing the number of the French speaking population as this is its chance to acquire (in Bourdieu's terms (1986) "social capital" for the future negotiations with economically powerful Flanders. It is, therefore, interesting to see how Flemish and Walloon representatives will define a common ground with regard to the specificity and practicality of language and integration criteria.

The new citizenship law was adopted on 25 October 2012 in the plenary session of the Belgian Chamber of Representatives and sent to the Senate for further approval (Belgian H.R. 0476/021 2012). In the current form, the law requires linguistic, social, and economic integration of the applicants who must also be long term Belgian residents. In what regards the controversial issue of language criteria, a compromise seems to have been reached: the requirement of "knowledge of one of the national languages" has been agreed upon, but the reciprocity of the integration process has not (Belgian H.R. 0476/021 2012). More exactly, a citizenship applicant who has undertaken their integration parcours in Wallonia before settling in Flanders with the intention of becoming Belgian will start a new path of integration in Flanders. Therefore, the focus could now go towards the conditions that will be created in order to achieve the required levels of integration in the particular communities and whether they will be perceived as incentive for integration or barriers to integration.

\section{ACKNOWLEDGEMENTS}

An earlier version of this paper was presented at the ECSA-C Conference in Ottawa, April 2012. The author would like to thank Dr. Elke Winter and Dr. Alison Harell for their support and valuable suggestions. Thanks go also to the members of the ECSA-C panel, as well as RERA anonymous reviewers and editors for their extremely useful comments. 


\section{REFERENCES}

Béland, Daniel, and AndreéLecours. 2005. "The Politics of Territorial Solidarity: Nationalism and Social Policy Reform in Canada, the United Kingdom, and Belgium." Comparative Political Studies 38 (6): 676-703.

Belgian Federal Public Service Employment, Labour and Social Dialogue. 2009. L'Immigration en Belgique: Effectifs, Mouvements et Marche du Travail. Accessed December 20, 2012. http://www.emploi.belgique.be/publicationDefault.aspx?id=28778.

Belgian H.R. 0476/001. 2010. Proposition de Loi Modifiant le Code de la Nationalité Belge Afin de Rendre l'Acquisition de la Nationalité Belge Neutre du Point de Vue de l'Immigration, October 27. http://www.lachambre.be/FLWB/PDF/53/0476/53K0476001.pdf.

Belgian H.R. 0574/001. 2010. Proposition de Loi Modifiant le Code de la Nationalité Belge, November 17. http://www.lachambre.be/FLWB/PDF/53/0574/53K0574001.pdf.

Belgian H.R. 0618/ 001. 2010. Proposition de Loi Instaurant le Code de la citoyenneté, November 18. http://www.lachambre.be/FLWB/PDF/53/0618/53K0618001.pdf.

Belgian H.R. 0601/001. 2010. Proposition de Loi Modifiant le Code de la Nationalité Belge, November 18. http://www.lachambre.be/FLWB/PDF/53/0601/53K0601001.pdf.

Belgian H.R. 0494/002. 2010. Proposition de Loi Modifiant le Code de la Nationalité Belge, November 19. http://www.lachambre.be/FLWB/PDF/53/0494/53K0494002.pdf.

Belgian H.R. 0742/001. 2010. Proposition de Loi Portant Modification du Code de la Nationalité Belge, November 30. http://www.lachambre.be/FLWB/PDF/53/0742/53K0742001.pdf.

Belgian H.R. 0601/002. 2010. Proposition de Loi Portant Modification du Code de la Nationalité Belge, November 30. http://www.lachambre.be/FLWB/PDF/53/0601/53K0601002.pdf.

Belgian H.R. 0494/003. 2010. Proposition de Loi Modifiant le Code de la Nationalité Belge, December 6. http://www.lachambre.be/FLWB/PDF/53/0494/53K0494003.pdf.

Belgian H.R. 0476/002. 2010. Proposition de Loi Modifiant le Code de la Nationalité Belge Afin de Rendre l'Acquisition de la Nationalité Belge Neutre du Point de Vue de l'Immigration, December 10. http://www.lachambre.be/FLWB/pdf/53/0476/53K0476002.pdf.

Belgian H.R. 0476/003. 2010. Proposition de Loi Modifiant le Code de la Nationalité Belge Afin de Rendre l'Acquisition de la Nationalité Belge Neutre du Point de Vue de l'Immigration, December 13. http://www.lachambre.be/FLWB/pdf/53/0476/53K0476003.pdf.

Belgian H.R. 0476/004. 2010. Proposition de Loi Modifiant le Code de la Nationalité Belge Afin de Rendre l'Acquisition de la Nationalité Belge Neutre du Point de Vue de l'Immigration, December 14. http://www.lachambre.be/FLWB/pdf/53/0476/53K0476004.pdf.

Belgian H.R. 0476/005. 2010. Proposition de Loi Modifiant le Code de la Nationalité Belge Afin de Rendre l'Acquisition de la Nationalité Belge Neutre du Point de Vue de l'Immigration, December 14. http://www.lachambre.be/FLWB/pdf/53/0476/53K0476005.pdf.

Belgian H.R. 0476/006. 2011. Proposition de Loi Modifiant le Code de la Nationalité Belge Afin de Rendre l'Acquisition de la Nationalité Belge Neutre du Point de Vue de l'Immigration, January 11. http://www.lachambre.be/FLWB/pdf/53/0476/53K0476006.pdf. 
Belgian H.R. 0476/007. 2011. Proposition de Loi Modifiant le Code de la Nationalité Belge Afin de Rendre 1'Acquisition de la Nationalité Belge Neutre du Point de Vue de l'Immigration, January 19. http://www.lachambre.be/FLWB/pdf/53/0476/53K0476007.pdf. Belgian H.R. 0476/008. 2011. Proposition de Loi Modifiant le Code de la Nationalité Belge Afin de Rendre 1'Acquisition de la Nationalité Belge Neutre du Point de Vue de l'Immigration, January 24. http://www.lachambre.be/FLWB/pdf/53/0476/53K0476008.pdf.

Belgian H.R. 0476/009. 2011. Proposition de Loi Modifiant le Code de la Nationalité Belge Afin de Rendre 1'Acquisition de la Nationalité Belge Neutre du Point de Vue de l'Immigration, June 10. http://www.lachambre.be/FLWB/pdf/53/0476/53K0476009.pdf.

Belgian H.R. 0476/010. 2011. Proposition de Loi Modifiant le Code de la Nationalité Belge Afin de Rendre l'Acquisition de la Nationalité Belge Neutre du Point de Vue de l'Immigration, June 22. http://www.lachambre.be/FLWB/pdf/53/0476/53K0476010.pdf.

Belgian H.R. 0476/012. 2011. Proposition de Loi Modifiant le Code de la Nationalité Belge Afin de Rendre 1'Acquisition de la Nationalité Belge Neutre du Point de Vue de l'Immigration, September 27. http://www.lachambre.be/FLWB/pdf/53/0476/53K0476012.pdf.

Belgian H.R. 0476/016. 2012. Proposition de Loi Modifiant le Code de la Nationalité Belge Afin de Rendre l'Acquisition de la Nationalité Belge Neutre du Point de Vue de l'Immigration, July 24. http://www.lachambre.be/FLWB/pdf/53/0476/53K0476016.pdf.

Belgian H.R. 0476/021. 2012. Proposition de Loi Modifiant le Code de la Nationalité Belge Afin de Rendre l'Acquisition de la Nationalité Belge Neutre du Point de Vue de l'Immigration, October 25. http://www.lachambre.be/FLWB/pdf/53/0476/53K0476021.pdf. Bourdieu, Pierre. 1986. "The Forms of Capital." In Handbook of Theory and Research for the Sociology of Education, edited by J. Richardson, 241-258. New York: Greenwood.

Brubaker, Rogers. 1992.Citizenship and Nationhood in France and Germany. Cambridge: Harvard University Press.

De Clerck, Stefaan. 2010a. Avant-projet de loi portant modification du Code de la Nationalité Belge and Exposes des motifs. http://www.stefaandeclerck.be/fr/projet-de-loi-modificationde-la-nationalit $\% \mathrm{C} 3 \% \mathrm{~A} 9 / 1049$. . 2010b. PROJET DE LOI portant modification du Code de la nationalité belge, Expose

des Motifs. Accessed April 24 2012.http://www.stefaandeclerck.be/fr/projet-de-loimodification-de-la-nationalit\%C3\%A9/1049.

European Commission. 2003. Decree on the Flemish Integration Policy. http://ec.europa.eu/ewsi/UDRW/images/items/docl_1294_743451124.pdf

Flemish Integration (Inburgering) Policy. www.inburgering.be/en/civic-integration-programme

Foblets, Marie-Claire, and ZeynepYanasmayan. 2010. "Language and Integration Requirements in Belgium: Discordances Between the Flemish Policy of «Inburgering» and the Federal Legislators' View(s) on the Integration of Newcomers and Migrants." In A Re-definition of Belonging? Language and Integration Tests in Europe, edited by Ricky van Oers, Eva Ersboll, and Dora Kostakopoulou (with E. Guild \& J. Niessen), 271-305. Leiden, Boston: MartinusNijhoff Publishers.

Ghaffar-KucherAmeena. 2006. "Assimilation, Integration, or Isolation? (Re)Framing the Education of Immigrants."Current Issues in Comparative Education 9(1): 3-7.

Gsir, Sonia. "Belgique: Intégration et Cohésion Sociale." Paper presented at the Conference of the Commision Fédérale des Etrangers Quelle Intégration? Welche Integration, Bienne, Switzerland, November 2006. 
Gysen, Sara, Henk Kuijper, and Piet Van Avermaet.2009. "Language Testing in the Context of Immigration and Citizenship: The Case of the Netherlands and Flanders (Belgium).’'Language Assessment Quarterly 6 (1): 1-15.

Jacobs, Dirk. "Becoming Part of a Disintegrating Nation-State. Political Inclusion of Foreigners in Belgium, a Polity in Crisis." Paper presented at the Conference of Russell Sage Foundation Fear and Anxiety over National Identity: Contrasting North American and European Experiences and Public Debates on Immigrant and Second Generation Integration, New York City, NY, December 2011.

Jacobs, Dirk, and Andrea Rea. 2006. "Construction and Import of Ethnic Categorisations:

'Allochthones' in the Netherlands and Belgium.” FEEM Working Paper No. 68.2006. doi:

10.2139/ssrn.897903.

Joppke, Christian. 2010a. "The Inevitable Lightening of Citizenship." Archives Européenes de Sociologie 51 (1): 9-32.

Joppke, Christian. 2010b. Citizenship and Immigration. Cambridge: Polity Press.

Koutroubas, Theodoros, BenoîtRihoux, Ward Vloeberghs, and ZeynepYanasmayan. 2011."The Complex Community Mosaic in Belgium.'In Interculturalism. Europe and its Muslims in Search of Sound Societal Models, edited by Michael Emerson, 55-76.Brussels: Centre for European Policy Studies (CEPS).

La Derniere Heure (DH). 2012. Comment devenir belge. July 16. http://www.dhnet.be/infos/belgique/article/401920/comment-devenir-belge.html.

Lewis-Beck, Michael S., Alan Bryman, and Tim Futing Liao. 2004. The Sage Encyclopedia of Social Science Research Methods, Vol.1. London: Sage Publications.

Le Texier, Emmanuelle. 2006. « Du modèle républicain à des modèles culturalistes hybrides: les cas belges et français ». In Les Politiques d'intégration en Europe: le 'contrat d'intégration' en question, edited by Emmanuelle Le Texier and Inès Michalowski, 2-3. Varietate Concordia.Accessed December 20, 2012. http://gbf.typepad.com/concordia/2006/04/les_politiques.html.

Loobuyck, Patrick, and Dirk Jacobs. 2009. "Self-government, Immigration and Integration in Flanders: Political Opportunities, Tensions and Challenges." In Immigration and SelfGovernment of Minority Nations, edited by RicardZapata-Barrero, 103-121. Brussels: Lang. Loobuyck, Patrick, and Dirk Jacobs.2009."Migration and Integration Policy in Belgium and Flanders." In Belgian Society and Politics 2009-The Diversity Challenge for the Left, Annual Review 3: 19-27. http://www.bruessel.diplo.de/contentblob/3051328/Daten/1111506/DD_Loobuyck.pdf

Martiniello, Marco, and Andrea Rea. "Belgium's Immigration Policy Brings Renewal and Challenges". Migration Information Source. October, 2003, http://www.migrationinformation.org/feature/display.cfm?ID=164.

Merton, Robert K. 1975. "Thematic Analysis in Science: Notes on Holton's Concept." Science, New Series, 188 (4186): 335-38.

OECD report.2010. Naturalisation and the Socio-economic Integration of Immigrants and Their Children. Brussels.

http://irfam.org/assets/File/english/naturalisation_and_integration_of_immigrants_and_their_

Seidle, F. Leslie.2008. "Belgium. Country profile." In Comparative Research and Analysis: Country Profiles: Belgium, Canada, Denmark, France, Germany, Netherlands, Sweden, United Kingdom and U.S.A.: and a Few Research notes, edited by Seidle, F. Leslie and, 
Aude-Claire Fourot, 1-11. Montreal, Quebec: Commission de Consultation sur les Pratiques d'Accommodement Reliées aux Différences Culturelles.

Van Oers, Ricky, Eva Ersbøll, and DoraKostakopoulou.2010. A Re-Definition of Belonging?: Language and Integration Tests in Europe. Leiden, Netherlands: Koninklijke Brill NV.

Wautelet, Patrick. 2012. Belgian Parliament likely to adopt a major change of citizenship law in October 2012. European Union Democracy Observatory (EUDO) Citizenship. http://eudocitizenship.eu/news/citizenship-news/686-belgian- parliament-likely-to-adopt-a-majorchange-of-citizenship-law-in-october- 2012\#.UDFtxt1mTib

Winter, Elke. 2011. Us, Them and Others: Pluralism and National Identity in Diverse Societies, Toronto: University of Toronto Press.

Wright, Sue. 2008. "Citizenship Tests in Europe-Editorial Introduction." International Journal on Multicultural Societies10 (1): 1-9.

Woehrling, José. "Linguistic Requirements for Immigrants, Specifically with Regard to Languages that Enjoy Official Status in Part of the Territory." Paper presented at Séminaire sur la mondialisation, la libre-circulation et l'immigration, Barcelona, Spain, September 2007. http://www.cerium.ca/IMG/pdf/Woehrling-_Linguistic_requirements_for_immigrants.pdf.

Yanasmayan, Zeynep, and Marie-Claire Foblets. 2010. “Country Report Belgium.” In Integration and Naturalisation Tests: The New Way to European Citizenship, Centre for Migration Law. Nijmegen, Netherlands: Radboud University. http://www.ru.nl/law/cmr/projects/intec/.

Zapata-Barrero, Ricard (ed.). 2009. Citizenship Policies in the Age of Diversity Europe at the Crossroads. GRITIM. Barcelona: Universitat Pompeu Fabra. 
Correct citation: Madularea, Adina. 2012. "Le Code de la Nationalité Belge: A Citizenship Law in the Making." Review of European and Russian Affairs 7 (1): 1-19.

Published by the Centre for European Studies at Carleton University, Ottawa, Canada. Available online at: www.carleton.ca/rera/

RERA is an electronic academic peer-reviewed journal that publishes graduate, post-graduate, and young scholarly works. Topics relate to the European Union, its Member States, the former Soviet Union, and Central and Eastern Europe. The journal is a joint project supported by the Canada-Europe Transatlantic Dialogue - a cross-Canada research network supported by the Social Sciences and Humanities Research Council of Canada (SSHRC) - along with the Institute of European, Russian and Eurasian Studies (Carleton University) and its associated research unit, the Centre for European Studies.

RERA aims to provide an accessible forum for research, to promote high standards of research and scholarship, and to foster communication among young scholars.

\section{Contact:}

Carleton University

The Centre for European Studies

1103 Dunton Tower

1125 Colonel By Drive

Ottawa, ON

K1S 5B6

Canada

Tel: +01 613 520-2600 ext. 1179; E-mail: rera-journal@,carleton.ca

\section{Creative Commons License}

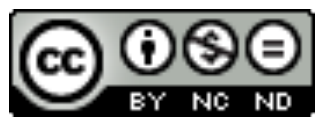

http://creativecommons.org/licenses/by-nc-nd/3.0/

This Working Paper is licensed under a Creative Commons Attribution-Non-CommercialNo Derivs 3.0 Unported License (CC BY-NC-ND 3.0).

Articles appearing in this publication may be freely quoted and reproduced provided the source is acknowledged. No use of this publication may be made for resale or other commercial purposes.

ISSN: $1718-4835$

(C) 2012 The Author(s) 